\title{
THE EFFECTS OF NITROGEN AND ZINC APPLICATIONS ON THE YIELD, YIELD COMPONENTS AND OIL RATIO OF SAFFLOWER (Carthamus tinctorius L.) UNDER SEMI-ARID CONDITIONS
}

\author{
Haliloglu, H. $^{{ }^{*}}-$ Beyyavas, V. $^{2}$ \\ ${ }^{1}$ Department of Field Crops, Faculty of Agriculture, Harran University, Sanliurfa, Turkey \\ ${ }^{2}$ Suruc Vocational College, Harran University, Sanliurfa, Turkey \\ *Corresponding author \\ e-mail: haliloglu@harran.edu.tr; phone: +90-530-205-0794
}

(Received $6^{\text {th }}$ Mar 2019; accepted $3^{\text {rd }}$ May 2019)

\begin{abstract}
This study was conducted in order to determine the effect of Nitrogen $(\mathrm{N})$ and Zinc $(\mathrm{Zn})$ on the yield, yield components and oil ratio of safflower under semi-arid conditions in 2011-2012 and 20122013 growing seasons. Field trials was established in the randomized complete blocks design split plots with three replications in the experimental area Department of Field Crops of Agricultural Faculty, Harran University in Turkey. In the study, $\mathrm{N}$ applications $\left(\mathrm{N}_{0}=\right.$ no fertilization, $\mathrm{N}_{5}=50 \mathrm{~kg} \mathrm{ha}^{-1}$, $\mathrm{N}_{10}=100 \mathrm{~kg} \mathrm{ha}^{-1}$ and $\left.\mathrm{N}_{15}=150 \mathrm{~kg} \mathrm{ha}^{-1}\right)$ were placed in the main plots, $\mathrm{Zn}$ applications $\left(\mathrm{Zn}_{0}=\right.$ no fertilization, $\mathrm{Zn}_{1}=10 \mathrm{~kg} \mathrm{ha}^{-1}, \mathrm{Zn}_{2}=20 \mathrm{~kg} \mathrm{ha}^{-1}$ and $\left.\mathrm{Zn}_{3}=30 \mathrm{~kg} \mathrm{ha}^{-1}\right)$ were in the sub-plots. Seed yield ( $\mathrm{kg}$ $\left.\mathrm{ha}^{-1}\right)$, seed yield per plant $\left(\mathrm{g} \mathrm{plant}^{-1}\right)$, plant height $(\mathrm{cm})$, number of heads per plant (pieces plant $\left.{ }^{-1}\right)$, number of seeds per head (pieces head $\left.{ }^{-1}\right), 1000$ seeds weight $(\mathrm{g})$, dry petal yield $\left(\mathrm{g} \mathrm{plant}^{-1}\right)$, oil ratio (\%) and biomass yield $\left(\mathrm{kg} \mathrm{ha}^{-1}\right)$ were examined in the study. The results indicated that; the highest seed yields were obtained from the $\mathrm{N}_{15}\left(1171\right.$ and $1651 \mathrm{~kg} \mathrm{ha}^{-1}$ ) and $\mathrm{Zn}_{3}\left(1233\right.$ and $1675 \mathrm{~kg} \mathrm{ha}^{-1}$ ) applications in both years. $\mathrm{N}$ applications comparing control plots affected the yield per plant, plant height, number of heads per plant, number of seeds per head, 1000 seed weight and biomass yield, had negative effect on the dry petal yield and oil ratio. Zn applications according to control plots whereas had positive effects on the seed yield per plant and number of heads per plant but had no significant effect on the dry petal yield and oil ratio. NxZn interactions affected the seed yield, number of heads per plant, number of seeds per head and biomass yield. $150 \mathrm{~kg} \mathrm{~N} \mathrm{ha}^{-1}$ and $30 \mathrm{~kg} \mathrm{Zn} \mathrm{ha}^{-1}$ should be given to safflower under semi-arid conditions.
\end{abstract}

Keywords: Carthamus, nutrients, dry petal, oil ratio, interaction

\section{Introduction and literature review}

Sanliurfa is the hottest province of Southeastern Anatolia Region in Turkey. Harran Plain is located in the Sanliurfa city where continental climate, summers are very hot and dry and the winter are relatively temperate (Kose et al., 2018). Average annual rainfall is around $350-400 \mathrm{~mm}$. Most of the rainfall falls in the winter season. Therefore, it is great important to cultivate drought-resistant plants in areas where irrigation is not possible. Safflower plant can be grown in this region under drought.

Safflower plant (Carthamus tinctorius L.) has quite various usage by stem, leaves, seeds and flowers. It is a very important industrial plant neglected and could not reach the place deserved. It is an historical species and it was cultivated in the Middle East 3000 years ago (Knowles, 1982). All parts of the plant are used in the treatment of various illnesses in India and Pakistan (Nimbkar, 2002). The flowers are used in the food, cosmetic, dye and pharmaceutical industries (Dajue and Mundel, 1996; Abd ElMohsen and Mahmoud, 2013). Safflower was reported to be one of the alternative 
plants that can be considered in irrigated areas with its tolerance to salinity and weeds, and especially due to its high tolerance to cold and heat climatic conditions in arid regions (Emongor et al., 2015).

Safflower (Carthamus tinctorius L.) is one of the most important annual oil plants to be grown in winter season (Eslam, 2010; Gursoy et al., 2018). It is more resistant to drought and lower temperatures than other non-selective oil crops in terms of growth requirements safflower can also be grown in fallow areas especially in arid regions (Johnson et al., 1993). Due to these properties, safflower can be an alternative crop in crop rotation vs. wheat, barley, lentil and tobacco. It can help to alleviate the shortage of vegetable oil demand of Turkey (Eryigit et al., 2015; Kose, 2017). Safflower has yellow, red, orange and cream-colored flowers with thorny and thorn less forms, and it has been used for he production of edible oil and biofuels having 30-45\% fat on average in its seeds (Demir and Kara, 2018).

Safflower seeds contain $13-46 \%$ oil, about $90 \%$ of this oil consisted of unsaturated fatty acids (oleic and linoleic acid) (Johnson et al., 1993; Belgin et al., 2007). Safflower oil containing an average of $75 \%$ linoleic acid (Weiss, 2000), and there are also its antioxidant effects and tocopherols with high vitamin E values. Therefore, safflower oil is used in diets applied by cardiovascular patients and has a great importance because of its anti-cholesterol effects (Pongracz et al., 1995).

Safflower petals are very important as a source of medicinal preparations, natural food colour and dyes for colouring fabrics. In addition to the colouring properties, safflower petals are used for curing several chronic diseases such as hypertension, coronary heart ailments, rheumatism and male and female fertility problems (Rajvanshi, 2005).

Since the safflower oil is suitable for biodiesel production, intensive researches on biodiesel production from safflower oil are carried out (Ogut and Oguz, 2006; Nosheen et al., 2011). The cartharmia substance obtained from the safflower is great important as a natural dye raw material (Nagaraj et al., 2001; Emongor, 2010). Especially the petals are used as food dyes and spices have potential to increase income from the unit area in the arid regions (Esendal, 2001).

In addition, some plant nutrients were found to be effective together with irrigation in direct to yield and yield components. Two of these important nutrients are nitrogen and zinc.

Nitrogen fertilizers are one of the important inputs in dry rainfed agricultural systems. In order to obtain optimum yield and quality product in these regions, sufficient amount of nitrogen in suitable time and form should be given to the plant. Excessive or insufficient $\mathrm{N}$ fertilizer applications result in some economic losses, excessive nitrogen application causes environmental problems over time (Grant, 2006). It was reported by many researches that the nitrogen fertilizer affected on the safflower growth, yield and quality properties significantly (Ahmed et al., 1985; El-Nakhlawy, 1991; Ibrahim, 1994). N fertilization increased seed yield (Strasil and Vorlicek, 2002); 300,600 and $900 \mathrm{~kg} \mathrm{ha}^{-1} \mathrm{~N}$ applications according to the control plots increased the biomass of safflower by $13.4 \%, 15.3 \%$ and $22.9 \%$ respectively (Haghighati, 2010). Nitrogen was effective on the vegetative and reproductive stages of safflower (Bitarafan et al., 2011); nitrogen applications increased seed yield $44.6-60.5 \%$ on average compared to the control plots (Singh and Singh, 2013); seed yield, 1000 seed weight, number of heads per plant and plant height were affected positively (Eryigit et al., 2015), and plant height and seed yield were increased (Revant Nathan et al., 2018) by 
the nitrogen fertilization. The effect of nitrogen may vary according to the amount, time and form of the application.

Zinc applications exhibited positive effect on the oil yield and seed quality, and besides, do the plant more resistant to drought conditions were reported by many researchers (Mengel, 2001; Khoshgoftarmanesh, 2010; Taha et al., 2013). Zinc has an important effect on the oil yield and quality, seed yield and biomass production (Lewis and McFarlane, 1986); Zinc sulphate application under water stress conditions increased seed yield, biomass and biological yield than control plots (Lakzayi, 2015); zinc application comparing central increased seed yield and number of heads per plant (Gulmezoglu and Aytac, 2016).

In this study, it is important to determine the effect of $\mathrm{N}$ and Zinc separately and in combination on the safflower crop under semi-arid climate conditions in the Harran Plain conditions. There have not been done such a study before under Harran plain conditions, because of that this study is important. As it is known, the genotypic structure of each plant is affected more or less from the environmental factors. The dose of the plant nutrient that is applied in a region has a good result, may not work well under any other environmental conditions. Therefore, it is great important to conduct these studies and determine the most appropriate doses in every ecological condition.

This study was carried out to asses the appropriate doses of the nitrogen and zinc on to seed yield and seed quality as well as disseminate the cultivation of safflower under semi-arid climatic conditions.

\section{Materials and methods}

Remzibey-05 safflower cultivar with yellow flowers, spiny leaves and head was used as plant material. The experimental area has a flat topography. It is well-drained deep, stone-free, with high clay content (54-56\%). Soil pH is between 7.3-7.2, the salt content is $0.088-0.092 \%$, and low in organic material $1.25-1.19 \%$. In addition, the amount of pure $\mathrm{N} 25-19 \mathrm{~kg} \mathrm{ha}^{-1}, \mathrm{P}_{2} \mathrm{O}_{5}$ amount of pure $27-30 \mathrm{~kg} \mathrm{ha}^{-1}$ and $\mathrm{K}_{2} \mathrm{O} 1086-1129 \mathrm{~kg} \mathrm{ha}^{-1}$ was determined (Table 1 ).

Table 1. Some soil properties of experimental area (Anonymous, 2012)

\begin{tabular}{c|c|c|c|c|c|c|c|c|c|c}
\hline Years & $\begin{array}{c}\text { Total Salt } \\
\mathbf{( \% )}\end{array}$ & $\begin{array}{c}\text { Lime } \\
\mathbf{( \% )}\end{array}$ & $\begin{array}{c}\text { Sand } \\
\mathbf{( \% )}\end{array}$ & $\begin{array}{c}\text { Clay } \\
\mathbf{( \% )}\end{array}$ & $\begin{array}{c}\text { Silt } \\
\mathbf{( \% )}\end{array}$ & $\begin{array}{c}\text { Organic } \\
\text { Matter (\%) }\end{array}$ & $\mathbf{p H}$ & $\begin{array}{c}\mathbf{N} \\
\left(\mathbf{k g ~ h a}^{-1}\right)\end{array}$ & $\begin{array}{c}\mathbf{P}_{2} \mathbf{O}_{5} \\
\left(\mathbf{k g ~ h a}^{-1} \mathbf{)}\right.\end{array}$ & $\begin{array}{c}\mathbf{K}_{2} \mathbf{O} \\
\left(\mathbf{k g ~ h a}^{-\mathbf{1}} \mathbf{)}\right.\end{array}$ \\
\hline 2011 & 0.088 & 5.1 & 25.12 & 54 & 20.20 & 1.25 & 7.3 & 25 & 27 & 1086 \\
2012 & 0.092 & 5.4 & 26.03 & 56 & 20.32 & 1.19 & 7.2 & 19 & 30 & 1129 \\
\hline
\end{tabular}

Field trials were setup employing according to the randomized complete block design split plots with three replications in the experimental area Department of Field Crops of Agricultural Faculty, Harran University Eyyubiye Campus (3706'59.1" N $38^{\circ} 49^{\prime} 15.8^{\prime \prime}$ E) (altitude $=510 \mathrm{~m}$ from sea level) (Fig. 1).

Each plot consisted of $5 \mathrm{~m}$ long with 5 rows. Inter-row and intra-row spaces were 35 and $15 \mathrm{~cm}$ respectively (Fig. 2). After experimental area had been ploughed, herbicide (Trifluarin active ingredient) was applied by a sprayer before planting. Then, Diskharrowing was practiced for trial seedbed preparation tillage.

The sowing was practiced on $5^{\text {th }}$ November, 2011 and $3^{\text {th }}$ November, 2012 by the experimental drill. $2 \mathrm{~m}$ alley was left between each plot. After the emergence, thinning 


$$
-7594-
$$

was practised in the stages of 3 or 4 leaves. The cultural practices (hoeing, weeding and pest management) were performed when needed in accordance with the conventional methods.

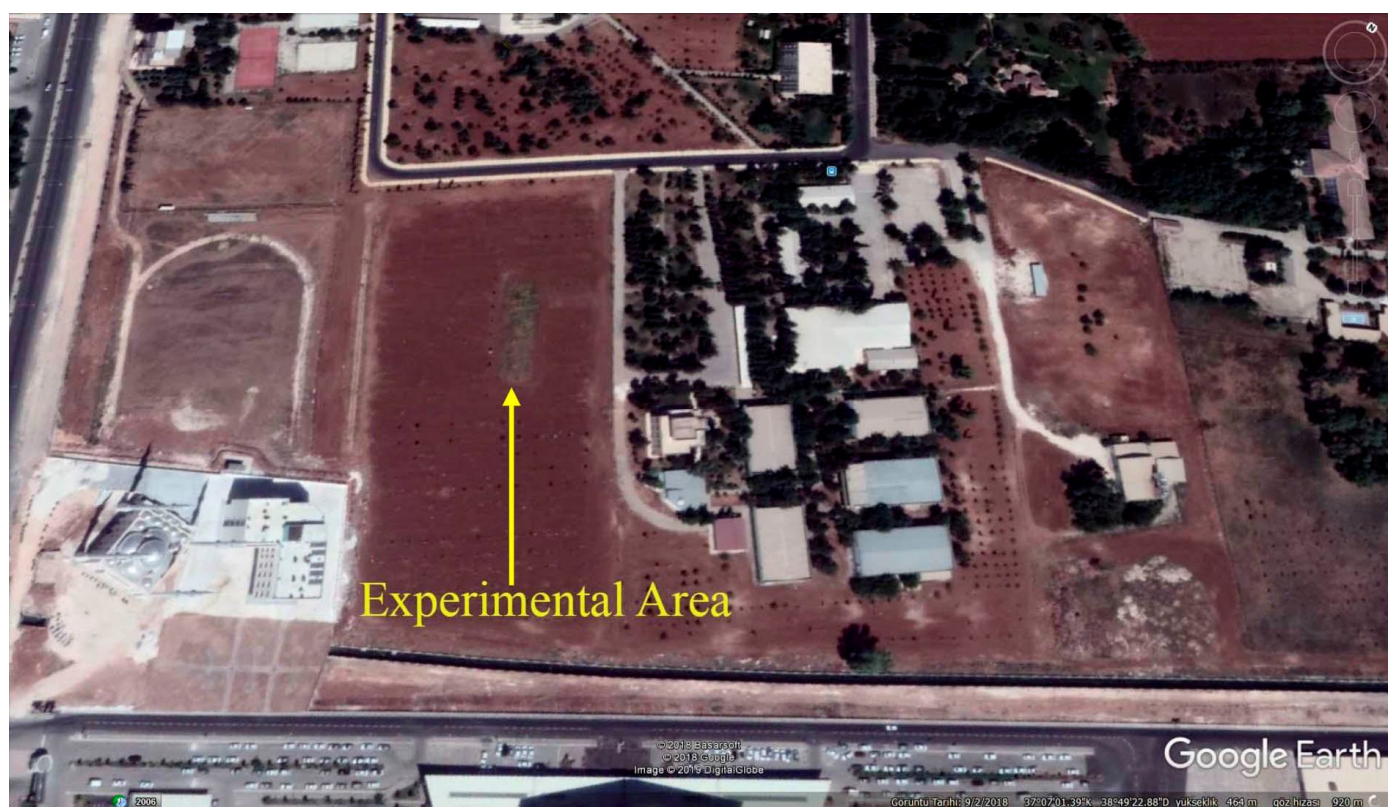

Figure 1. The map of the experimental area

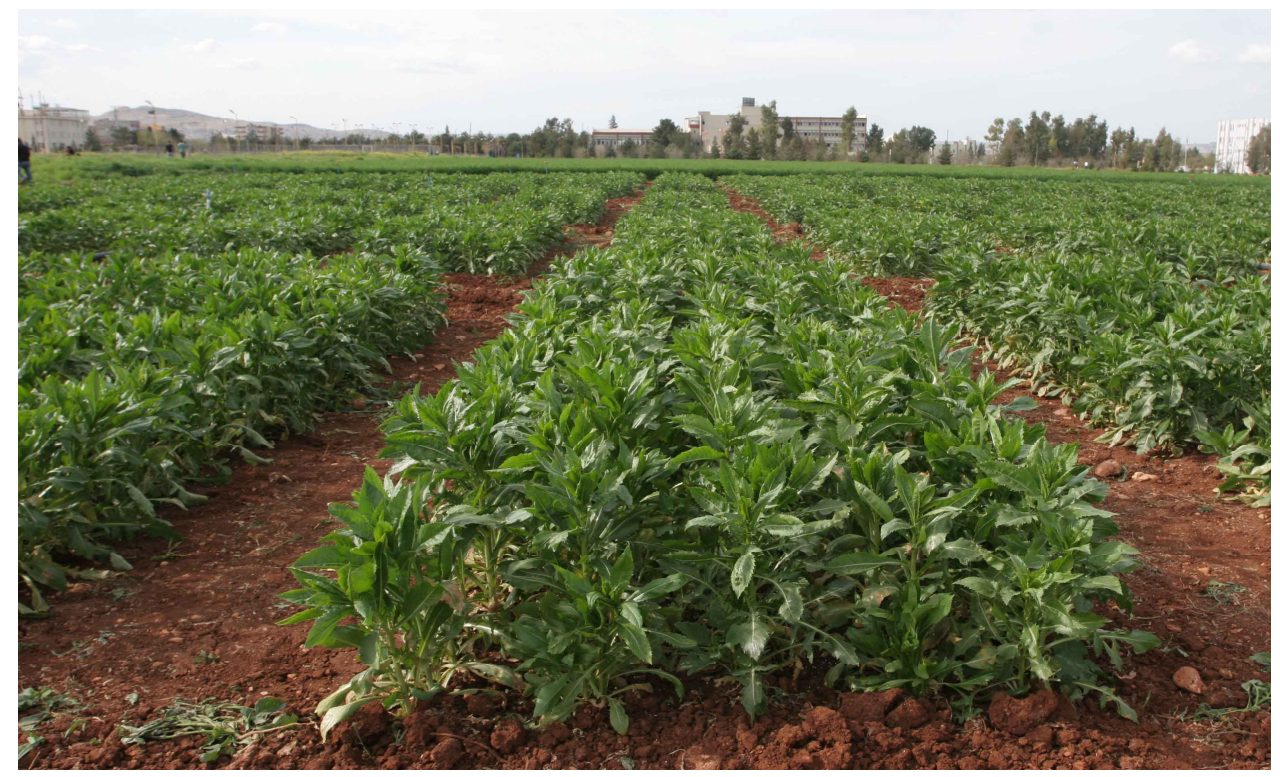

Figure 2. Experimental area

In both growing seasons, total precipitation occurred close to each other. The average temperature $\left(13.76^{\circ} \mathrm{C}\right)$ for the $2011-2012$ growing season was very close to the average for long years $\left(13.68^{\circ} \mathrm{C}\right.$ ), but the average temperature for the 2012-2013 growing period $\left(15.31{ }^{\circ} \mathrm{C}\right)$ was higher than the average of the first year and long years of the experiment (Table 2). The higher average temperature in the second year of the 
experiment and the higher monthly precipitation, especially in May, may have caused the better development of the plant.

Table 2. Some of meteorological characteristics for long term (1929-2013) and 20011-2013 period in Sanliurfa, Turkey (Anonymous, 2013)

\begin{tabular}{|c|c|c|c|c|c|c|c|}
\hline & \multicolumn{3}{|c|}{ 2011-2012 } & \multicolumn{3}{|c|}{ 2012-2013 } & 1929-2013 \\
\hline Months & $\begin{array}{c}\text { Average } \\
\text { monthly } \\
\text { temp. } \\
\left({ }^{\circ} \mathrm{C}\right)\end{array}$ & $\begin{array}{l}\text { Precipitation } \\
\quad\left(\mathrm{kg} \mathrm{m}^{-2}\right)\end{array}$ & $\begin{array}{c}\text { Average } \\
\text { relative } \\
\text { humidity } \\
(\%)\end{array}$ & $\begin{array}{c}\text { Average } \\
\text { monthly } \\
\text { temp. } \\
\left({ }^{\circ} \mathrm{C}\right)\end{array}$ & $\begin{array}{l}\text { Precipitation } \\
\quad\left(\mathrm{kg} \mathrm{m}^{-2}\right)\end{array}$ & $\begin{array}{c}\text { Average } \\
\text { relative } \\
\text { humidity } \\
(\%)\end{array}$ & $\begin{array}{c}\text { Average of } \\
\text { long-term } \\
\left({ }^{\circ} \mathrm{C}\right)\end{array}$ \\
\hline November & 9.4 & 62.1 & 53.7 & 14.9 & 68.4 & 65.6 & 12.9 \\
\hline December & 7.4 & 47.1 & 57.4 & 8.3 & 142.8 & 73.0 & 7.5 \\
\hline January & 5.5 & 170.9 & 81.0 & 6.8 & 86.8 & 69.5 & 5.4 \\
\hline February & 5.8 & 95.8 & 57.0 & 9.3 & 107.2 & 73.6 & 6.8 \\
\hline March & 9.7 & 35.8 & 47.3 & 12.9 & 12.1 & - & 10.7 \\
\hline April & 19.3 & 23.3 & 42.4 & 18.4 & 18.0 & 44.9 & 16.0 \\
\hline May & 22.4 & 42.3 & 40.8 & 22.9 & 56.2 & 43.4 & 22.1 \\
\hline June & 30.6 & 5.8 & 21.2 & 29.0 & - & 24.0 & 28.0 \\
\hline Average & 13.76 & & 50.1 & 15.31 & & 49.25 & 13.68 \\
\hline Total & & 483.1 & & & 491.5 & & \\
\hline
\end{tabular}

In the study, $\mathrm{N}$ applications $\left(\mathrm{N}_{0}=\right.$ no fertilization, $\mathrm{N}_{5}=50 \mathrm{~kg} \mathrm{ha}^{-1}, \mathrm{~N}_{10}=100 \mathrm{~kg} \mathrm{ha}^{-1}$ and $\mathrm{N}_{15}=150 \mathrm{~kg} \mathrm{ha}^{-1}$ ) were placed in the main plots, $\mathrm{Zn}$ applications were assigned in the sub-plots $\left(\mathrm{Zn}_{0}=\right.$ no fertilization, $\mathrm{Zn}_{1}=10 \mathrm{~kg} \mathrm{ha}^{-1}, \mathrm{Zn}_{2}=20 \mathrm{~kg} \mathrm{ha}^{-1}$ and $\mathrm{Zn}_{3}=30 \mathrm{~kg}$ $\left.\mathrm{ha}^{-1}\right)$. Half of the nitrogen was applied in the form of Ammonium Sulphate $(21 \%)$ with the sowing, the remaining half in the form of ammonium nitrate $(33 \%)$ at the branching stage. All the zinc in the form of $\mathrm{ZnSO} 47 \mathrm{H}_{2} \mathrm{O}(23 \%)$ was applied with the sowing in 5$6 \mathrm{~cm}$ next to the plant rows and 5-6 $\mathrm{cm}$ deep by hand. Superphosphate (pure phosphorus $80 \mathrm{~kg} \mathrm{ha}^{-1}$ ) was applied as basal fertilizer at sowing.

Harvest was performed by hand for the seed and biomass yield from the remaining area $\left(4 \mathrm{~m} \times 1.05 \mathrm{~m}=4.2 \mathrm{~m}^{2}\right)$ by thrown away the side effects of $0.5 \mathrm{~m}$ at the beginning and end of 3 rows in the middle of each plots on $5^{\text {th }}$ June, 2013 and $6^{\text {th }}$ June, 2013. Seed yield per plant $\left(\mathrm{g} \mathrm{plant}^{-1}\right)$, plant height $(\mathrm{cm})$, number of heads per plant (pieces plant ${ }^{-1}$ ), number of seeds per head ( pieces head $\left.{ }^{-1}\right), 1000$ seed weight $(\mathrm{g})$ and dry petal yield $(\mathrm{g}$ plant $^{-1}$ ) were determined on randomly selected 10 plants (Esendal et al., 1992). A sufficient amount of seed $(10 \mathrm{~g})$ was grinded for each application and dried in the oven at $70{ }^{\circ} \mathrm{C}$ for 72 hours. $5 \mathrm{~g}$ of each sample boiled for 6 hours by using hexane in soxhlet extraction device and so on oil ratios $(\%)$ were scored.

The data was subjected to analysis of variance utilizing the JMP 11 (SAS Institute 2013, USA) statistical program in the randomized complete blocks design split plots and averages were grouped by the Tukey HSD test $(p \leq 0.05)$.

\section{Results and discussion}

In the analysis of variance (ANOVA) according to the combined years of the properties examined in the trial, statistical differences were found between years. Due to that the results of each year were analyzed separately. 


\section{Seed yield $\left(\mathrm{kg} \mathrm{ha}^{-1}\right)$}

$\mathrm{N}_{15}$ application gave the highest seed yield (1171 and $\left.1651 \mathrm{~kg} \mathrm{ha}^{-1}\right)$ in both years of the experiment. Strasil and Vorlicek (2002), Singh and Singh (2013), Eryigit et al. (2015) and Revant Nathan et al. (2018) reported that the nitrogen fertilization increased yield is consistent with the research results. The highest seed yield in $\mathrm{Zn}$ application was obtained from the $\mathrm{Zn}_{3}$ application (1233 and $1675 \mathrm{~kg} \mathrm{ha}^{-1}$ ) in both years. Taha et al. (2013), Lakzayi (2015) and Gulmezoglu and Aytac (2016) observed that the zinc applications increased seed yield comparing to the control. In the first year of the experiment $\mathrm{N}_{15} \times \mathrm{Zn}_{3}$ interaction $\left(1463 \mathrm{~kg} \mathrm{ha}^{-1}\right)$, in the second year $\mathrm{N}_{0} \times \mathrm{Zn}_{3}(1887 \mathrm{~kg}$ $\left.\mathrm{ha}^{-1}\right), \mathrm{N}_{10} \times \mathrm{Zn}_{2}\left(1865 \mathrm{~kg} \mathrm{ha}^{-1}\right)$ and $\mathrm{N}_{15} \times \mathrm{Zn}_{3}$ (1900 $\mathrm{kg} \mathrm{ha}^{-1}$ ) interactions gave the highest seed yield (Table 3). $\mathrm{N}_{15} \times \mathrm{Zn}_{3}$ interaction gave the highest seed yield (1463 and $1900 \mathrm{~kg} \mathrm{ha}^{-1}$ ) in both years shows that the application in these doses increase the seed yield. High yield in second year comparing that of first year can be attributed to fluctuating climate and environmental factors.

\section{Seed yield per plant (g plant $\left.{ }^{-1}\right)$}

Statistically significant differences were found between $\mathrm{N}$ and $\mathrm{Zn}$ applications in both years. $\mathrm{N}_{15}(8.44$ and $11.98 \mathrm{~g})$ and $\mathrm{Zn}_{3}(8.68$ and $11.25 \mathrm{~g})$ applications gave the highest seed yield per plant in both years. In general, obtained the better yields in the second year than the first year can be attributed to environmental and climatic conditions. $\mathrm{N}_{15} \times \mathrm{Zn}_{3}$ interaction gave the highest seed yield (10.83 and $\left.13.57 \mathrm{~g}\right)$ in both years indicates that the application at these doses increases seed yield per plant (Table 3).

Seed yield per plant is a factor that directly affects seed yield per hectare. As a matter of fact, the highest values obtained from the $\mathrm{N}_{15}$ and $\mathrm{Zn}_{3}$ applications for seed yield per hectare confirmed the research results. Eryigit et al. (2015) and Revant Nathan et al. (2018) reported that the nitrogen fertilization increased seed yield per plant, and Taha et al. (2013); Gulmezoglu and Aytac (2016) zinc fertilization as well.

\section{Plant height (cm)}

$\mathrm{N}_{5}$ application $(142.0 \mathrm{~cm})$ in the first year, $\mathrm{N}_{15}$ application $(141.6 \mathrm{~cm})$ in the second year gave the highest plant height values (Table 1). Khalil et al. (2013) and Eryigit et al. (2015) report that the nitrogen fertilization increases plant height which was consistent with the research results. Similar results were also reported by Katar et al. (2012) and Bitarafan et al. (2011).

As the zinc applications had not any effects on the plant height in the first year, $\mathrm{Zn}_{2}$ application gave the highest plant height $(140.3 \mathrm{~cm})$ in the second year. $\mathrm{N}_{5} \times \mathrm{Zn}_{2}$ interaction $(144.8 \mathrm{~cm})$ in the first year, $\mathrm{N}_{0} \times \mathrm{Zn}_{3}(143.3 \mathrm{~cm})$ and $\mathrm{N}_{5} \times \mathrm{Zn}_{2}(143.0 \mathrm{~cm})$ interactions in the second year gave the highest plant height scores (Table 3).

Plant height is significantly affected by environmental factors. The highest plant height scores from the different applications in both years can be due to the fact that the plants grow in all kinds of natural areas that are open to various impacts and they are very much under different environmental conditions during the growth and development periods (Arslan and Bayraktar, 2015). However, the highest plant height from the $\mathrm{N}_{5} \times \mathrm{Zn}_{2}(144.8$ and $143.0 \mathrm{~cm})$ interaction in both years showed that the application at these doses increases the plant height. 
Table 3. Averages and groups of main (N), sub variables (Zn) and interactions (NxZn) for seed yield $\left(\mathrm{kg} \mathrm{ha}^{-1}\right)$, seed yield per plant $\left(\mathrm{g}\right.$ plant $\left.{ }^{-1}\right)$ and plant height $(\mathrm{cm})$

\begin{tabular}{|c|c|c|c|c|c|c|c|}
\hline \multirow{2}{*}{\multicolumn{2}{|c|}{$\begin{array}{c}\text { Treatments } \\
\mathrm{N}\end{array}$}} & \multicolumn{2}{|c|}{$\begin{array}{l}\text { Seed yield } \\
\left(\mathrm{kg} \mathrm{ha}^{-1}\right)\end{array}$} & \multicolumn{2}{|c|}{$\begin{array}{l}\text { Seed yield per plant } \\
\left(\text { g plant }^{-1}\right)\end{array}$} & \multicolumn{2}{|c|}{$\begin{array}{l}\text { Plant height } \\
\text { (cm) }\end{array}$} \\
\hline & & 2011-12 & 2012-13 & 2011-12 & $2012-13$ & 2011-12 & 2012-13 \\
\hline \multicolumn{2}{|c|}{$\mathrm{N}_{0}$} & $1045 b^{*}$ & $1612 b^{*}$ & $8.07 \mathrm{a}^{*}$ & $9.85 c^{*}$ & $139.7 b^{*}$ & $140.1 b^{*}$ \\
\hline \multicolumn{2}{|c|}{$\mathrm{N}_{5}$} & $985 \mathrm{c}$ & $1565 \mathrm{c}$ & $6.55 \mathrm{~b}$ & $11.10 \mathrm{ab}$ & $142.0 \mathrm{a}$ & $139.1 \mathrm{~b}$ \\
\hline \multicolumn{2}{|c|}{$\mathrm{N}_{10}$} & $1147 \mathrm{a}$ & $1594 \mathrm{~b}$ & $8.43 \mathrm{a}$ & $10.14 b c$ & $139.6 \mathrm{~b}$ & $135.3 \mathrm{c}$ \\
\hline \multicolumn{2}{|c|}{$\mathrm{N}_{15}$} & $1171 \mathrm{a}$ & $1651 \mathrm{a}$ & $8.44 \mathrm{a}$ & $11.98 \mathrm{a}$ & $138.2 \mathrm{~b}$ & $141.6 \mathrm{a}$ \\
\hline \multicolumn{2}{|c|}{$\mathrm{Zn}$} & 2011-12 & 2012-13 & 2011-12 & $2012-13$ & 2011-12 & $2012-13$ \\
\hline \multicolumn{2}{|c|}{$\mathrm{Zn}_{0}$} & $1110 b^{*}$ & $1473 c^{*}$ & $8.03 \mathrm{~b}^{*}$ & $10.65 b^{*}$ & $140.4 \mathrm{~ns}$ & $138.4 b^{*}$ \\
\hline \multicolumn{2}{|c|}{$\mathrm{Zn}_{1}$} & $1020 \mathrm{c}$ & $1674 \mathrm{a}$ & $7.83 \mathrm{~b}$ & $11.35 \mathrm{a}$ & 140.2 & $137.6 \mathrm{c}$ \\
\hline \multicolumn{2}{|c|}{$\mathrm{Zn}_{2}$} & $985 \mathrm{c}$ & $1602 \mathrm{~b}$ & $6.94 \mathrm{c}$ & $9.81 \mathrm{c}$ & 139.4 & $140.3 \mathrm{a}$ \\
\hline \multicolumn{2}{|c|}{$\mathrm{Zn}_{3}$} & $1233 \mathrm{a}$ & $1675 \mathrm{a}$ & $8.68 \mathrm{a}$ & $11.25 \mathrm{a}$ & 139.5 & $139.7 \mathrm{ab}$ \\
\hline \multicolumn{2}{|c|}{ Interactions } & 2011-12 & 2012-13 & 2011-12 & 2012-13 & 2011-12 & 2012-13 \\
\hline \multirow{4}{*}{$\mathrm{N}_{\mathrm{o}}$} & $\mathrm{Zn}_{0}$ & 1207 bcd* & $1461 \mathrm{gh}^{*}$ & $8.54 b^{*}$ & $10.57 \mathrm{~cd}^{*}$ & $140.6 \mathrm{abc}^{*}$ & 138.2 b-f* \\
\hline & $\mathrm{Zn}_{1}$ & $1158 \mathrm{~b}-\mathrm{e}$ & $1698 \mathrm{c}$ & $7.69 \mathrm{bd}$ & $11.31 \mathrm{bc}$ & $138.5 \mathrm{bc}$ & $136.7 \mathrm{c}-\mathrm{g}$ \\
\hline & $\mathrm{Zn}_{2}$ & $984 \mathrm{gh}$ & $1560 \mathrm{de}$ & $7.57 \mathrm{bcd}$ & $10.30 \mathrm{~cd}$ & $139.4 \mathrm{bc}$ & $142.3 \mathrm{ab}$ \\
\hline & $\mathrm{Zn}_{3}$ & $1243 \mathrm{~b}$ & $1887 \mathrm{a}$ & 8.49 bce & $12.65 \mathrm{ab}$ & $140.2 \mathrm{abc}$ & $143.3 \mathrm{a}$ \\
\hline \multirow{4}{*}{$\mathrm{N}_{5}$} & $\mathrm{Zn}_{0}$ & $1015 \mathrm{fg}$ & $1414 \mathrm{~h}$ & $6.58 \mathrm{cde}$ & $10.35 \mathrm{~cd}$ & $139.2 \mathrm{bc}$ & 139.9 a-e \\
\hline & $\mathrm{Zn}_{1}$ & $894 \mathrm{~h}$ & $1599 \mathrm{~d}$ & $6.56 \mathrm{de}$ & $9.25 \mathrm{~d}$ & $141.6 \mathrm{ab}$ & $136.2 \mathrm{efg}$ \\
\hline & $\mathrm{Zn}_{2}$ & $921 \mathrm{gh}$ & $1564 \mathrm{de}$ & $6.14 \mathrm{e}$ & $9.90 \mathrm{~cd}$ & $144.8 \mathrm{a}$ & $143.0 \mathrm{a}$ \\
\hline & $\mathrm{Zn}_{3}$ & $1111 \mathrm{de}$ & $1683 \mathrm{c}$ & $6.92 \mathrm{cde}$ & $13.67 \mathrm{a}$ & $142.5 \mathrm{ab}$ & $137.4 \mathrm{c}-\mathrm{g}$ \\
\hline \multirow{4}{*}{$\mathrm{N}_{10}$} & $\mathrm{Zn}_{0}$ & $1209 \mathrm{bc}$ & $1494 \mathrm{fg}$ & $8.79 \mathrm{~b}$ & $10.52 \mathrm{~cd}$ & $142.6 \mathrm{ab}$ & $133.3 \mathrm{~g}$ \\
\hline & $\mathrm{Zn}_{1}$ & $923 \mathrm{gh}$ & $1790 \mathrm{~b}$ & $8.99 \mathrm{~b}$ & $10.31 \mathrm{~cd}$ & $142.6 \mathrm{ab}$ & $136.6 \mathrm{~d}-\mathrm{g}$ \\
\hline & $\mathrm{Zn}_{2}$ & $932 \mathrm{gh}$ & $1865 \mathrm{a}$ & $7.94 \mathrm{bcd}$ & $9.56 \mathrm{~d}$ & $135.5 \mathrm{c}$ & $135.3 \mathrm{fg}$ \\
\hline & $\mathrm{Zn}_{3}$ & $1115 \mathrm{cde}$ & 12281 & $8.00 \mathrm{bcd}$ & $10.14 \mathrm{~cd}$ & $137.6 \mathrm{bc}$ & $135.8 \mathrm{efg}$ \\
\hline \multirow{4}{*}{$\mathrm{N}_{15}$} & $\mathrm{Zn}_{0}$ & $1012 \mathrm{fg}$ & $1523 \mathrm{ef}$ & $8.72 \mathrm{~b}$ & $10.44 \mathrm{~cd}$ & $139.1 \mathrm{bc}$ & $142.3 \mathrm{ab}$ \\
\hline & $\mathrm{Zn}_{1}$ & 1106 ef & $1607 \mathrm{~d}$ & $8.08 \mathrm{bc}$ & $10.22 \mathrm{~cd}$ & $138.1 \mathrm{bc}$ & $141.0 \mathrm{abc}$ \\
\hline & $\mathrm{Zn}_{2}$ & 1105 ef & $1419 \mathrm{~h}$ & $6.13 \mathrm{e}$ & $9.48 \mathrm{~d}$ & $137.9 \mathrm{bc}$ & $140.8 \mathrm{a}-\mathrm{d}$ \\
\hline & $\mathrm{Zn}_{3}$ & $1463 \mathrm{a}$ & $1900 \mathrm{a}$ & $10.83 \mathrm{a}$ & $13.57 \mathrm{a}$ & $137.6 \mathrm{bc}$ & $142.5 \mathrm{ab}$ \\
\hline $\mathrm{CV} \%$ & & 13.74 & 11.61 & 16.22 & 10.12 & 10.96 & 12.40 \\
\hline \multicolumn{8}{|c|}{ F value } \\
\hline & $\mathrm{N}$ & $85.97 * *$ & $42.61 * *$ & 37.40 ** & $51.03 * *$ & $9.38 * *$ & $44.19 * *$ \\
\hline & $\mathrm{Zn}$ & $141.55 * *$ & $295.95 * *$ & $24.63 * *$ & $27.01 * *$ & $0.97 \mathrm{~ns}$ & $8.90 * *$ \\
\hline & NxZn & $34.05 * *$ & $379.11 * *$ & $9.28 * *$ & $15.70 * *$ & $5.73 * *$ & $7.88 * *$ \\
\hline
\end{tabular}

$*$ Means followed by different letters within columns are significantly different $(\mathrm{p} \leq 0.05)$

$* \mathrm{p} \leq 0.05, * * \mathrm{p} \leq 0.01, \mathrm{~ns}$ : non-significant

\section{Number of heads per plant (pieces plant ${ }^{-1}$ )}

$\mathrm{N}_{10}$ application gave the highest number of heads per plant $\left(17.7\right.$ pcs plant $\left.^{-1}\right)$ in the first year, $\mathrm{N}_{15}$ application gave the highest number of heads per plant $\left(21.2\right.$ pcs $\left._{\text {plant }}{ }^{-1}\right)$ in the second year. Bitarafan et al. (2011) and Eryigit et al. (2015) reported that nitrogen fertilization increases the number of heads per plant. In the first year of the experiment $\mathrm{Zn}_{3}\left(18.7\right.$ pes plant $\left.^{-1}\right)$, in the second year $\mathrm{Zn}_{1}$ and $\mathrm{Zn}_{3}$ applications (20.3 pes plant ${ }^{-1}$ ) 
gave the highest number of heads per plant. Gulmezoglu and Aytac (2016) declared that Zinc application increased the number of heads per plant compared to the control plots in a research which was consistent with the research results. $\mathrm{N}_{10} \mathrm{xZn_{1 }}\left(19.7\right.$ pcs plant $\left.^{-1}\right)$ and $\mathrm{N}_{10} \times \mathrm{Zn}_{3}$ (19.6 pcs plant ${ }^{-1}$ ) interactions in the first year of the experiment, $\mathrm{N}_{5} \mathrm{xZn} \mathrm{n}_{3}$ (22.8 pcs plant $\left.^{-1}\right)$ in the second year gave the highest number of heads per plant (Table 4).

Table 4. Averages and groups of main (N), sub variables (Zn) and interactions (NxZn) for number of heads per plant (pieces plant ${ }^{-1}$ ), number of seeds per head (pieces head ${ }^{-1}$ ) and 1000 seed weight $(g)$

\begin{tabular}{|c|c|c|c|c|c|c|c|}
\hline \multirow{2}{*}{\multicolumn{2}{|c|}{$\begin{array}{c}\text { Treatments } \\
\mathrm{N}\end{array}$}} & \multicolumn{2}{|c|}{$\begin{array}{l}\text { Number of heads per } \\
\text { plant (pieces plant }^{-1} \text { ) }\end{array}$} & \multicolumn{2}{|c|}{$\begin{array}{l}\text { Number of seeds per } \\
\text { head (pieces head }^{-1} \text { ) }\end{array}$} & \multicolumn{2}{|c|}{$\begin{array}{l}1000 \text { seed weight } \\
\text { (g) }\end{array}$} \\
\hline & & 2011-12 & 2012-13 & 2011-12 & 2012-13 & 2011-12 & 2012-13 \\
\hline \multicolumn{2}{|c|}{$\mathrm{N}_{0}$} & $17.5 \mathrm{ab}^{*}$ & $19.2 b^{*}$ & $14.3 \mathrm{ab}^{*}$ & $11.7 b^{*}$ & $29.11 \mathrm{ab}^{*}$ & $28.77 b^{*}$ \\
\hline \multicolumn{2}{|c|}{$\mathrm{N}_{5}$} & $16.9 \mathrm{~b}$ & $19.2 \mathrm{~b}$ & $12.5 \mathrm{~b}$ & $11.6 \mathrm{~b}$ & $27.86 \mathrm{~b}$ & $29.45 \mathrm{ab}$ \\
\hline \multicolumn{2}{|c|}{$\mathrm{N}_{10}$} & $17.7 \mathrm{a}$ & $18.7 \mathrm{~b}$ & $14.5 \mathrm{a}$ & $12.6 \mathrm{a}$ & $29.76 \mathrm{ab}$ & $29.85 \mathrm{a}$ \\
\hline \multicolumn{2}{|c|}{$\mathrm{N}_{15}$} & $17.2 \mathrm{~b}$ & $21.2 \mathrm{a}$ & $15.5 \mathrm{a}$ & $12.9 \mathrm{a}$ & $30.01 \mathrm{a}$ & $29.88 \mathrm{a}$ \\
\hline \multicolumn{2}{|c|}{$\mathrm{Zn}$} & 2011-12 & 2012-13 & 2011-12 & 2012-13 & 2011-12 & 2012-13 \\
\hline \multicolumn{2}{|c|}{$\mathrm{Zn}_{0}$} & $17.3 b^{*}$ & $19.6 b^{*}$ & $14.8 \mathrm{ab}^{*}$ & $12.4^{\mathrm{ns}}$ & $29.68^{\mathrm{ns}}$ & $29.94 \mathrm{a}^{*}$ \\
\hline \multicolumn{2}{|c|}{$\mathrm{Zn}_{1}$} & $17.2 \mathrm{~b}$ & $20.3 \mathrm{a}$ & $13.2 \mathrm{~b}$ & 12.2 & 29.80 & $29.25 \mathrm{ab}$ \\
\hline \multicolumn{2}{|c|}{$\mathrm{Zn}_{2}$} & $16.1 \mathrm{c}$ & $18.2 \mathrm{c}$ & $13.2 \mathrm{~b}$ & 12.3 & 28.58 & $28.62 \mathrm{~b}$ \\
\hline \multicolumn{2}{|c|}{$\mathrm{Zn}_{3}$} & $18.7 \mathrm{a}$ & $20.3 \mathrm{a}$ & $15.6 \mathrm{a}$ & 11.9 & 28.69 & $30.15 \mathrm{a}$ \\
\hline \multicolumn{2}{|c|}{ Interaction } & 2011-12 & 2012-13 & 2011-12 & 2012-13 & 2011-12 & 2012-13 \\
\hline \multirow{4}{*}{$\mathrm{N}_{\mathrm{o}}$} & $\mathrm{Zn}_{0}$ & $17.2 \mathrm{cde}^{*}$ & $22.1 \mathrm{ab}^{*}$ & $15.5 \mathrm{abc}^{*}$ & $12.0 \mathrm{~d}-\mathrm{g}^{*}$ & $30.73^{\mathrm{ns}}$ & $30.97 \mathrm{ab}^{*}$ \\
\hline & $\mathrm{Zn}_{1}$ & $18.8 \mathrm{ab}$ & 20.2 b-e & $13.2 \mathrm{bc}$ & $12.1 \mathrm{c}-\mathrm{f}$ & 29.33 & $28.98 \mathrm{ab}$ \\
\hline & $\mathrm{Zn}_{2}$ & $16.2 \mathrm{efg}$ & 19.6 efg & $13.1 \mathrm{bc}$ & $11.1 \mathrm{efg}$ & 28.07 & $28.94 \mathrm{ab}$ \\
\hline & $\mathrm{Zn}_{3}$ & $17.7 \mathrm{bcd}$ & $22.1 \mathrm{abc}$ & $15.9 a b c$ & $11.1 \mathrm{efg}$ & 28.32 & $29.88 \mathrm{ab}$ \\
\hline \multirow{4}{*}{$\mathrm{N}_{5}$} & $\mathrm{Zn}_{0}$ & $18.5 \mathrm{abc}$ & $17.9 \mathrm{gh}$ & $11.3 \mathrm{c}$ & $11.7 \mathrm{~d}-\mathrm{g}$ & 27.97 & $29.05 \mathrm{ab}$ \\
\hline & $\mathrm{Zn}_{1}$ & $15.5 \mathrm{fg}$ & $21.7 \mathrm{a}-\mathrm{d}$ & $13.0 \mathrm{bc}$ & $10.6 \mathrm{fg}$ & 27.98 & $28.90 \mathrm{ab}$ \\
\hline & $\mathrm{Zn}_{2}$ & $16.4 \mathrm{~d}-\mathrm{g}$ & 15.41 & $12.9 \mathrm{bc}$ & $13.8 \mathrm{abc}$ & 27.70 & $28.88 \mathrm{ab}$ \\
\hline & $\mathrm{Zn}_{3}$ & 17.3 cde & $22.8 \mathrm{a}$ & $12.9 \mathrm{bc}$ & $10.4 \mathrm{~g}$ & 27.81 & $31.72 \mathrm{a}$ \\
\hline \multirow{4}{*}{$\mathrm{N}_{10}$} & $\mathrm{Zn}_{0}$ & $19.0 \mathrm{ab}$ & $18.0 \mathrm{fgh}$ & $14.1 \mathrm{abc}$ & $12.7 \mathrm{~b}-\mathrm{e}$ & 29.37 & $29.66 \mathrm{ab}$ \\
\hline & $\mathrm{Zn}_{1}$ & $19.7 \mathrm{a}$ & 19.3 e-h & $14.2 \mathrm{abc}$ & $14.0 \mathrm{ab}$ & 31.20 & $30.59 \mathrm{ab}$ \\
\hline & $\mathrm{Zn}_{2}$ & $15.3 \mathrm{~g}$ & 20.0 def & $14.5 \mathrm{abc}$ & $12.5 \mathrm{~b}-\mathrm{e}$ & 29.12 & $28.53 \mathrm{~b}$ \\
\hline & $\mathrm{Zn}_{3}$ & $19.6 \mathrm{a}$ & $17.6 \mathrm{~h}$ & $15.4 \mathrm{abc}$ & $11.1 \mathrm{efg}$ & 29.33 & $30.64 \mathrm{ab}$ \\
\hline \multirow{4}{*}{$\mathrm{N}_{15}$} & $\mathrm{Zn}_{0}$ & $16.8 \mathrm{def}$ & 20.3 b-e & $18.1 \mathrm{ab}$ & $13.2 \mathrm{a}-\mathrm{d}$ & 30.67 & $29.33 \mathrm{ab}$ \\
\hline & $\mathrm{Zn}_{1}$ & $15.4 \mathrm{~g}$ & $20.1 \mathrm{cde}$ & $12.4 \mathrm{c}$ & $12.0 \mathrm{~d}-\mathrm{g}$ & 30.67 & $28.52 \mathrm{~b}$ \\
\hline & $\mathrm{Zn}_{2}$ & $16.3 \mathrm{~d}-\mathrm{g}$ & $17.8 \mathrm{gh}$ & $12.3 \mathrm{c}$ & $11.7 \mathrm{~d}-\mathrm{g}$ & 29.42 & $28.10 \mathrm{~b}$ \\
\hline & $\mathrm{Zn}_{3}$ & 17.3 cde & 18.7 e-h & $19.0 \mathrm{a}$ & $14.7 \mathrm{a}$ & 29.30 & $29.12 \mathrm{ab}$ \\
\hline CV \% & & 8.56 & 10.38 & 17.26 & 10.60 & 5.93 & 4.20 \\
\hline \multicolumn{8}{|c|}{ F value } \\
\hline & $\mathrm{N}$ & $5.98 *$ & $33.28 * *$ & $5.21 *$ & $16.84 * *$ & $4.40 *$ & $3.53 *$ \\
\hline & $\mathrm{Zn}$ & $62.12 * *$ & $28.05 * *$ & $5.54 *$ & $1.81 \mathrm{~ns}$ & $2.09 \mathrm{~ns}$ & $6.37 *$ \\
\hline & $\mathrm{NxZn}$ & $24.18 * *$ & $26.38 * *$ & $3.32 *$ & $19.65 * *$ & $0.46 \mathrm{~ns}$ & $2.24 \mathrm{~ns}$ \\
\hline
\end{tabular}

*Means followed by different letters within columns are significantly different $(\mathrm{p} \leq 0.05)$

$* \mathrm{p} \leq 0.05, * * \mathrm{p} \leq 0.01, \mathrm{~ns}$ : non-significant 
The most important selection criteria for seed yield was the number of heads per plant. The number of heads is a property that is affected by the plant genetic structure, sowing density, fertilization and other environmental factors. Implemented that the difference between the results and applications of other researchers in terms of number of heads per plant could be caused by the variations in climate and soil structure of the location where the research was carried out and cultivar, and the differences between different cultural techniques, sowing and harvest dates.

\section{Number of seeds per head (pieces head-1)}

$\mathrm{N}_{10}$ and $\mathrm{N}_{15}$ applications gave the highest number of seeds per head in both years. The highest number of seeds per head by the nitrogen fertilization increased seed yield per plant, and therefore contributed positively to the seed yield per hectare in the trial. Strasil and Vorlicek (2002); Singh and Singh (2013) and Eryigit et al. (2015) reported that the nitrogen fertilization increased yield was consistent with our research results. As the $\mathrm{Zn}_{3}$ application gave the highest number of seeds per head (15.6 pcs head $\left.{ }^{-1}\right)$ in the first year, there were no statistically significant differences between the applications in the second year. $\mathrm{N}_{15} \mathrm{XZn}_{3}$ interaction gave the highest number of seeds per head (19.0 and 14.7 pcs head $^{-1}$ ) in two years (Table 4).

When examined the interactions, $\mathrm{N}_{15} \times \mathrm{Zn}_{3}$ interactions was promising. Bitarafan et al. (2011) indicated that nitrogen was effective in vegetative and reproductive development; Soleymani and Shahrajabian (2011), nitrogen increased the number of seeds per head, and Lewis and McFarlane (1986), $\mathrm{Zn}$ had an important role on the oil yield and quality, seed yield and biomass production are compatible with the research results. The number of seeds per head as well as the number of heads per plant were the important criterion for yield. The number of seeds per head was directly related to the head size and that can be affected fairly by genetic and environmental factors. Although an average of 100 flowers were formed in each safflower head, $20 \%$ of these flowers formed seed (Baydar, 2000).

\section{0 seed weight (g)}

$\mathrm{N}_{15}$ application (30.01 g) in the first year of the experiment, $\mathrm{N}_{10}$ and $\mathrm{N}_{15}$ applications ( 29.85 and $29.88 \mathrm{~g}$ ) in the second year gave the highest 1000 seed weight. Nitrogen fertilization gave the more 1000 seed weight values than control plots in both years. Bitarafan et al. (2011); Khalil et al. (2013) and Eryigit et al. (2015) reported that nitrogen doses increased 1000 seed weight comparing the control. Although $\mathrm{Zn}$ applications were insignificant in the first year, $\mathrm{Zn}_{0}$ and $\mathrm{Zn}_{3}$ applications (29.94 and $30.15 \mathrm{~g}$ ) gave the maximum 1000 seed weight values in the second year. At the same time, $\mathrm{N} \times \mathrm{Zn}$ interactions were in non-significant in the first year, $\mathrm{N}_{5} \times \mathrm{Zn}_{3}$ interaction gave the highest 1000 seed weight $(31.72 \mathrm{~g})$ in the second year (Table 4). These differences between years might be due to different soil and climate factors.

\section{Dry petal yield (g plant $\left.{ }^{-1}\right)$}

The highest petal yields ( 1.12 and $1.19 \mathrm{~g}$ ) were obtained from control $\mathrm{N}_{0}$ subject according to the $\mathrm{N}$ application, from the $\mathrm{Zn}_{0}(1.17$ and $1.27 \mathrm{~g})$ subject according to the $\mathrm{Zn}$ application in both years. $\mathrm{N}_{0} \times \mathrm{Zn}_{1}$ and $\mathrm{N}_{10} \times \mathrm{Zn}_{0}$ interactions gave the highest petal yield in the first (1.47 and $1.45 \mathrm{~g}$ ) and second year (1.70 and $1.65 \mathrm{~g})$ (Table 5). Control 
plots created more petal yields. This indicated that $\mathrm{N}$ and $\mathrm{Zn}$ applications had negative effects on the petal yields.

Table 5. Averages and groups of main (N), sub variables ( $\mathrm{Zn}$ ) and interactions (NxZn) for dry petal yield ( $g$ plant $\left.^{-1}\right)$, oil ratio (\%) and biomass yield (tons ha $^{-1}$ )

\begin{tabular}{|c|c|c|c|c|c|c|c|}
\hline \multirow{2}{*}{\multicolumn{2}{|c|}{$\begin{array}{c}\text { Treatments } \\
\mathrm{N}\end{array}$}} & \multicolumn{2}{|c|}{$\begin{array}{l}\text { Dry petal yield } \\
\left(\text { g plant }^{-1}\right)\end{array}$} & \multicolumn{2}{|c|}{$\begin{array}{l}\text { Oil ratio } \\
(\%)\end{array}$} & \multicolumn{2}{|c|}{$\begin{array}{c}\text { Biomass yield } \\
\left(\text { tons ha } \text { ha }^{-1}\right)\end{array}$} \\
\hline & & 2011-12 & 2012-13 & 2011-12 & 2012-13 & 2011-12 & 2012-13 \\
\hline \multicolumn{2}{|c|}{$\mathrm{N}_{0}$} & $1.12 \mathrm{a}^{*}$ & $1.19 \mathrm{a}^{*}$ & $30.0 \mathrm{a}^{*}$ & $31.3 \mathrm{a}^{*}$ & $5.808 \mathrm{c}^{*}$ & $9.238 \mathrm{ab}^{*}$ \\
\hline \multicolumn{2}{|c|}{$\mathrm{N}_{5}$} & $1.02 \mathrm{bc}$ & $1.04 \mathrm{c}$ & $30.1 \mathrm{a}$ & $31.4 \mathrm{a}$ & $6.617 \mathrm{a}$ & $8.612 \mathrm{~b}$ \\
\hline \multicolumn{2}{|c|}{$\mathrm{N}_{10}$} & $0.98 \mathrm{c}$ & $1.00 \mathrm{~d}$ & $29.5 \mathrm{~b}$ & $29.8 \mathrm{~b}$ & $6.058 \mathrm{~b}$ & $9.467 \mathrm{a}$ \\
\hline \multicolumn{2}{|c|}{$\mathrm{N}_{15}$} & $1.04 \mathrm{~b}$ & $1.12 \mathrm{~b}$ & $30.1 \mathrm{a}$ & $30.6 \mathrm{ab}$ & $6.217 \mathrm{~b}$ & $9.648 \mathrm{a}$ \\
\hline \multicolumn{2}{|c|}{$\mathrm{Zn}$} & 2011-12 & $2012-13$ & 2011-12 & 2012-13 & 2011-12 & 2012-13 \\
\hline \multicolumn{2}{|c|}{$\mathrm{Zn}_{0}$} & $1.17 \mathrm{a}^{*}$ & $1.27 \mathrm{a}^{*}$ & $29.9^{\text {ns }}$ & $30.4^{\mathrm{ns}}$ & $6.571 \mathrm{a}^{*}$ & $9.111 b^{*}$ \\
\hline \multicolumn{2}{|c|}{$\mathrm{Zn}_{1}$} & $1.08 \mathrm{~b}$ & $1.13 \mathrm{~b}$ & 30.0 & 30.9 & $5.742 \mathrm{c}$ & $9.600 \mathrm{a}$ \\
\hline \multicolumn{2}{|c|}{$\mathrm{Zn}_{2}$} & $1.05 \mathrm{c}$ & $1.11 \mathrm{~b}$ & 29.1 & 30.7 & $6.137 \mathrm{~b}$ & $9.215 \mathrm{~b}$ \\
\hline \multicolumn{2}{|c|}{$\mathrm{Zn}_{3}$} & $0.86 \mathrm{~d}$ & $0.84 \mathrm{c}$ & 29.7 & 31.0 & $6.250 \mathrm{~b}$ & $9.040 \mathrm{~b}$ \\
\hline \multicolumn{2}{|c|}{ Interaction } & 2011-12 & 2012-13 & 2011-12 & 2012-13 & 2011-12 & 2012-13 \\
\hline \multirow{4}{*}{$\mathrm{N}_{\mathrm{o}}$} & $\mathrm{Zn}_{0}$ & $1.13 \mathrm{~cd}^{*}$ & $1.27 \mathrm{c}^{*}$ & $29.9^{\mathrm{ns}}$ & 30.3 c-f* & $6.550 \mathrm{abc}^{*}$ & 9.420 bcd* $^{*}$ \\
\hline & $\mathrm{Zn}_{1}$ & $1.47 \mathrm{a}$ & $1.70 \mathrm{a}$ & 30.0 & $30.5 b-f$ & $4.700 \mathrm{~g}$ & $9.000 \mathrm{~cd}$ \\
\hline & $\mathrm{Zn}_{2}$ & $0.77 \mathrm{fg}$ & $0.71 \mathrm{fg}$ & 30.0 & $33.1 \mathrm{a}$ & $5.617 \mathrm{ef}$ & $8.640 \mathrm{de}$ \\
\hline & $\mathrm{Zn}_{3}$ & $1.09 \mathrm{~d}$ & $1.08 \mathrm{~d}$ & 30.2 & $31.2 \mathrm{~b}-\mathrm{e}$ & $6.367 \mathrm{a}-\mathrm{d}$ & $9.893 \mathrm{bc}$ \\
\hline \multirow{4}{*}{$\mathrm{N}_{5}$} & $\mathrm{Zn}_{0}$ & $1.20 \mathrm{c}$ & $1.24 \mathrm{c}$ & 30.3 & $30.7 b-f$ & $6.700 \mathrm{ab}$ & $7.667 \mathrm{f}$ \\
\hline & $\mathrm{Zn}_{1}$ & 0.84 ef & $0.84 \mathrm{e}$ & 29.7 & $31.0 \mathrm{~b}-\mathrm{f}$ & $6.533 \mathrm{abc}$ & $9.827 \mathrm{bc}$ \\
\hline & $\mathrm{Zn}_{2}$ & $1.17 \mathrm{c}$ & $1.20 \mathrm{c}$ & 30.3 & $31.8 \mathrm{a}-\mathrm{d}$ & $6.833 \mathrm{a}$ & $7.413 \mathrm{f}$ \\
\hline & $\mathrm{Zn}_{3}$ & 0.84 ef & $0.89 \mathrm{e}$ & 30.0 & $32.1 \mathrm{abc}$ & $6.400 \mathrm{a}-\mathrm{d}$ & $9.543 \mathrm{bcd}$ \\
\hline \multirow{4}{*}{$\mathrm{N}_{10}$} & $\mathrm{Zn}_{0}$ & $1.45 \mathrm{a}$ & $1.65 \mathrm{a}$ & 29.2 & 30.0 efg & $6.933 \mathrm{a}$ & $9.260 \mathrm{bcd}$ \\
\hline & $\mathrm{Zn}_{1}$ & $0.66 \mathrm{~h}$ & $0.63 \mathrm{~g}$ & 30.3 & $30.0 \mathrm{efg}$ & $5.967 \mathrm{c}-\mathrm{f}$ & $9.800 \mathrm{bc}$ \\
\hline & $\mathrm{Zn}_{2}$ & $1.09 \mathrm{~d}$ & $1.05 \mathrm{~d}$ & 29.2 & $28.6 \mathrm{~g}$ & $6.000 \mathrm{c}-\mathrm{f}$ & $10.900 \mathrm{a}$ \\
\hline & $\mathrm{Zn}_{3}$ & $0.75 \mathrm{~g}$ & $0.67 \mathrm{fg}$ & 29.3 & $30.6 \mathrm{~b}-\mathrm{f}$ & $5.333 \mathrm{fg}$ & 7.907 ef \\
\hline \multirow{4}{*}{$\mathrm{N}_{15}$} & $\mathrm{Zn}_{0}$ & $0.91 \mathrm{e}$ & $0.91 \mathrm{e}$ & 30.1 & $30.6 \mathrm{~b}-\mathrm{f}$ & $6.100 \mathrm{~b}-\mathrm{e}$ & $10.097 \mathrm{ab}$ \\
\hline & $\mathrm{Zn}_{1}$ & $1.35 \mathrm{~b}$ & $1.37 \mathrm{~b}$ & 30.1 & $32.2 \mathrm{ab}$ & $5.767 \mathrm{def}$ & $9.773 \mathrm{bc}$ \\
\hline & $\mathrm{Zn}_{2}$ & $1.17 \mathrm{~cd}$ & $1.45 \mathrm{~b}$ & 30.4 & $29.4 \mathrm{fg}$ & $6.100 \mathrm{~b}-\mathrm{e}$ & $9.907 \mathrm{bc}$ \\
\hline & $\mathrm{Zn}_{3}$ & $0.75 \mathrm{~g}$ & $0.74 \mathrm{f}$ & 29.4 & $30.2 \mathrm{~d}-\mathrm{g}$ & $6.900 \mathrm{a}$ & $8.817 \mathrm{de}$ \\
\hline $\mathrm{CV} \%$ & & 14.46 & 11.82 & 5.93 & 4.20 & 10.10 & 10.57 \\
\hline \multicolumn{8}{|c|}{ F Value } \\
\hline & $\mathrm{N}$ & $54.90 * *$ & $95.21 * *$ & $4.80 *$ & $20.35 * *$ & $24.03 * *$ & $26.97 * *$ \\
\hline & $\mathrm{Zn}$ & $312.99 * *$ & $425.03 * *$ & $1.25 \mathrm{~ns}$ & $2.91 \mathrm{~ns}$ & $28.82 * *$ & $8.24 * *$ \\
\hline & $\mathrm{NxZn}$ & $364.42 * *$ & $479.56 * *$ & $3.15 *$ & $12.06 * *$ & $17.78 * *$ & $38.28 * *$ \\
\hline
\end{tabular}

$*$ Means followed by different letters within columns are significantly different $(\mathrm{p} \leq 0.05)$

$* \mathrm{p} \leq 0.05, * * \mathrm{p} \leq 0.01, \mathrm{~ns}$ : non-significant

\section{Oil ratio (\%)}

$\mathrm{N}_{0}(30.0 \%), \mathrm{N}_{5}(30.1 \%)$ and $\mathrm{N}_{15}(30.1 \%)$ subjects gave the highest oil ratio in the first year, $\mathrm{N}_{0}$ and $\mathrm{N}_{5}(31.3$ and $31.4 \%)$ treatments in the second year and these formed in 
the same group. The formation of similar groups in two years reveals that the application of $\mathrm{N}$ did not have a positive effect on oil ratios. Kolsarici et al. (2005) and Elfadl et al. (2009) reported the similar results in their studies. Zn applications had not statistically significant in both years. Although $\mathrm{N} x \mathrm{Zn}$ interaction was insignificant in the first year, $\mathrm{N}_{0} \times \mathrm{Zn}_{2}$ interaction gave the highest oil ratio (33.1\%) in the second year (Table 5). These differences between the experimental years might be due to the various effects of environmental factors.

\section{Biomass yield (tons $\mathrm{ha}^{-1}$ )}

$\mathrm{N}_{5}$ application gave the highest biomass yield (6.617 tons ha $\left.{ }^{-1}\right)$ in the first year, $\mathrm{N}_{10}$ and $\mathrm{N}_{15}$ applications (9.467 and 9.648 tons $\mathrm{ha}^{-1}$ ) in the second year. When scores of characteristics for two years were evaluated, $\mathrm{N}$ applications generated the more biomass yield than the control plots. Several researchers reported that $\mathrm{N}$ applications increased biomass yield comparing to the control (Haghighati, 2010; Singh and Singh, 2013 and Revant Nathan et al., 2018). The highest biomass yield $\left(6.571\right.$ tons ha $\left.{ }^{-1}\right)$ in $\mathrm{Zn}$ applications was obtained from the $\mathrm{Zn}_{0}$ application in the first year, from the $\mathrm{Zn}_{1}$ application (9.600 tons ha $\left.{ }^{-1}\right)$ in the second year. $\mathrm{N}_{0} \times \mathrm{Zn}_{2}\left(6.933\right.$ tons ha $\left.{ }^{-1}\right)$ and $\mathrm{N}_{15} \times \mathrm{Zn}_{3}$ (6.900 tons $\left.\mathrm{ha}^{-1}\right)$ interactions in the first year, $\mathrm{N}_{10} \times \mathrm{Zn}_{2}\left(10.900\right.$ tons ha $\left.{ }^{-1}\right)$ interaction in the second year gave the highest biomass values (Table 5).

Biomass yields are affected by environmental factors. Especially, $\mathrm{N}$ applications with high precipitation enhance the vegetative development of the plant. Nitrogen with water, is the most vital nutrient. Therefore, it appears to be a nutrient that controls plant growth (Fageria, 2009). Zinc affects the nitrogen metabolism, starch formation and seed maturation in plants. Zinc a plant nutrient element necessary for the production of growth hormones (auxin hormone), and especially for the prolongation of the internode (Gardiner and Miller, 2008; McCauley et al., 2009). For these reasons, $\mathrm{N}$ and Zn applications are important in safflower production. The differences between $\mathrm{N} \times \mathrm{Zn}$ interactions in the research may have been caused by the diversities of climate and soil factors.

\section{Conclusions}

It was concluded that; the highest seed yield and seed yield per plant were obtained from the both $\mathrm{N}_{15} \times Z_{3}$ interaction and $\mathrm{N}_{15}$ and $\mathrm{Zn}_{3}$ applications. Although $\mathrm{N}$ applications had the positive effects comparing to the control plots on the seed yield per plant, plant height, number of heads per plant, number of seeds per head, 1000 seed weight and biomass yield and had no any positive effects on the dry petal yield and oil ratio. Zn applications had showed positive effects comparing to the control plots on the seed yield per plant and number of heads per plant and had negative effects on the oil ratio and dry petal yield. As a result of the research; the highest seed yield and seed yield per plant from the $\mathrm{N}_{15}$ and $\mathrm{Zn}_{3}$ applications were lower than those of the $\mathrm{N}_{15} \times \mathrm{Zn}_{3}$ interaction, and the doses of $150 \mathrm{~kg} \mathrm{~N} \mathrm{ha}^{-1}$ and $30 \mathrm{~kg} \mathrm{Zn} \mathrm{ha}^{-1}$ should be given together in $\mathrm{N}$ and $\mathrm{Zn}$ applications under semi-arid conditions. However, as each region has its own climate and soil conditions, it is useful to perform these studies where safflower cultivation is done. 
Acknowledgements. This study was financially supported by the Harran University Scientific Research Board (HÜBAK Project No: 0985).

\section{REFERENCES}

[1] Abd El-Mohsen, A. A., Mahmoud, G. O. (2013): Modeling the influence of nitrogen rate and plant density on seed yield, yield components and seed quality of safflower. American Journal of Experimental Agriculture 3(2): 336-360.

[2] Ahmed, Z., Medekkar, S., Mohammad, S. (1985): Response of safflower to nitrogen and phosphorus. - Indian Journal of Agronomy 39(1): 128-130.

[3] Anonymous (2012): GAP Agricultural Research Institute. - Sanliurfa, Turkey.

[4] Anonymous (2013): Meteorological data obtained from Sanliurfa Meteorological Station.

[5] Arslan, Y., Bayraktar, N. (2015): Effect of different levels Nitrogen and Phosphorus on the some yield components of Safflower (Carthamus tinctorius L.) in dry conditions. International Journal of agricultural and Wildlife Science (IJAWS) 1(2): 91-103.

[6] Baydar, H. (2000): Effects of gibberellic acid on male sterility, seed yield and oil and fatty acid syntheses of safflower (Carthamus tinctorius L.). - Tr. J. Biology 24(2000): 159-168.

[7] Belgin, C., Bilal, G., Mustafa, K. (2007): Oil content and fatty acid composition of some safflower (Carthamus tinctorius L.) varieties sown in spring and winter. - International Journal of Natural and Engineering Sciences 1(3): 11-15.

[8] Bitarafan, Z., Shirani-Rad, A. H., Delkhosh, B. (2011): Nitrogen rates and sowing date effect on yield and oil content of spring safflower. - International Journal of Science and Advanced Technology 1(6): 25-30.

[9] Dajue, L., Mundel, H. H. (1996): Safflower. Promoting the Conservation and Use of Underutilized and Neglected Crops. - 7. Institute of Plant Genetics and Crop Plant Reasarch, Gatersleben/International Plant Genetic Resources Institute, Rome.

[10] Demir, I., Kara, K. (2018): The effect of different environmental conditions on yield and oil rates of safflower (Carthamus tinctorius L.). - Fresenius Environmental Bulletin 27(2): 989-995.

[11] Esendal, E. (2001): Safflower production and research in Turkey. - Vth International Safflower Conference, Williston, North Dakota, Sidney, Montana, USA, July 23-27, pp. 203-206.

[12] Esendal, E., Kevseroglu, K., Uslu, N., Aytac, S. (1992): The effect of spring and winter planting on yield and important characters of safflower. - University of Ondokuz Mayis, Faculty of Agriculture, Years of Research, Project No: Z-044, pp. 119-121.

[13] Eslam, B. P., Monirifar, H., Ghassemi, M. T. (2010): Evaluation of late season drought effects on seed and oil yields in spring safflower genotypes. - Turk J. Agric. For. 34(2010): 373-380.

[14] El-Nakhlawy, F. S. (1991): Response of safflower to different levels of nitrogen, phosphorus and potassium. - Acta Agronomica Hungarica 40(1-2): 37-92.

[15] Elfadl, E., Reinbrecht, C., Frick, C., Claupein, W. (2009): Optimization of nitrogen rate and seed density for safflower (Carthamus tinctorius L.) production under low input farming conditions in temperate climate. - Field Crops Research 114(1): 2-13.

[16] Emongor, V. E. (2010): Safflower (Carthamus tinctorius L.) the underutilized and neglected crop: A review. - Asian Journal of Plant Sciences 9(6): 299-306.

[17] Emongor, V. E., Oagile, O., Kedikanetswe, B. (2015): Effects of plant population and season on growth and development of safflower (Carthamus tinctorius L.) as an ornamental plant. - Acta Horticulturae 1077(1077): 35-45.

[18] Eryigit, T., Yildirim, B., A. M., Kumlay, A. M., Sancaktaroglu, S. (2015): The Effects of different row distances and nitrogen fertilizer rates on yield and yield components of safflower (Carthamus tinctorious) under micro-climate conditions of Iğdır plain, Turkey. 
- 3rd International Conference on Biological, Chemical \& Environmental Sciences (BCES-2015) Sept. 21-22, 2015 Kuala Lumpur (Malaysia).

[19] Fageria, N. K. (2009): The Use of Nutrients in Crop Plants. - CRC Press, Boca Raton, FL.

[20] Gardiner, D. T., Miller, R. W. (2008): Soils in Our Environment. 11th Ed. Pearson/Prentice Hall, Upper Saddle Hill, NJ.

[21] Grant, C. (2006): Enhancing nitrogen use efficiency in dryland cropping systems on the Northern Great Plains. - 18th World Congress of Soil Science, Philadelphia, PA.

[22] Gulmezoglu, N., Aytac, Z. (2016): The influences of various zinc applications on seed yield and zinc uptake of safflower. - Soil Water Journal 5(2): 11-17.

[23] Gursoy, M., Basalma, D., Farzad Nofouzi, F. (2018): Effects of safflower cultivars (Carthamus tinctorius L.) on yield and yield components of different row and row spaces. - Selcuk Journal of Agriculture and Food Sciences 32(1): 20-28.

[24] Haghighati, A. (2010): Study on the effects of nitrogen and phosphorus fertilizers on the yield and oil content of safflower lines in drylands. - Research Journal of Agronomy 4(3): 57-62.

[25] Ibrahim, Y. M. (1994): Response of safflower to different nitrogen levels in United Arab Emirates. - Annals of Arid Zone 33(1): 77-78.

[26] Johnson, R. C., Stout, D. M., Bradley. V. L. (1993): A rich source of safflower germplasm. The U.S. Collection. - Proceeding Third International Safflower Conference, Beijing Botanical Garden Institute of Botany Chinese Academy of Sciences, 14-18 June, Beijing, China, pp. 202-208.

[27] Katar, D., Arslan, Y., Subasi, I. (2012): Effect of different doses of nitrogen on the yield and yield components of safflower (Carthamus tinctorius L.) under Ankara ecological conditions. - Suleyman Demirel University Journal of the Faculty of Agriculture 7(2): 56-64.

[28] Khalil, N. A. A., Dagash, Y. M., Yagoub, S. O. (2013): Effect of sowing date, irrigation intervals and fertilizers on safflower (Carthamus tinctorius L.) yield. - Discourse Journal of Agriculture and Food Sciences 1(5): 97-102.

[29] Khoshgoftarmanesh, A. H., Schulin, S., Chaney, R. L., Daneshbakhsh, B., Afyuni, M. (2010): Micronutrient-efficient genotypes for crop yield and nutritional quality in sustainable agriculture. A review. - Agron. Sustain. 30: 83-107.

[30] Knowles, P. F. (1982): Safflower: Genetics and Breeding. - In: Improvement of Oil-Seed and Industrial Crops by Induced Mutations. International Atomic Energy Agency, Vienna, pp. 89-101.

[31] Kolsarici, O., Allusoglu, S., Kaya, M. D. (2005): The effects of tillage and nitrogen doses on water use efficiency, soil moisture and seed characters of safflower (Carthamus tinctorius L.) in wheat-safflower rotation system. - VI ${ }^{\text {th }}$ International Safflower Conference, Istanbul, 6-10 June 2005, pp. 126-131.

[32] Kose, A. (2017): Agricultural performances of some safflower (Carthamus tinctorius L.) varieties under Eskisehir conditions. - Selcuk Journal of Agriculture and Food Science 31(2): 1-7.

[33] Kose, A., Hatipoglu, H., Arslan, H. (2018): Genotype reaction and effect of the sowing time under arid ecological conditions in Safflower (Carthamus tinctorius L.). - Fresenius Environmental Bulletin 27(5A): 3577-3586.

[34] Lakzayi, M. (2015): Influence of foliar application on safflower yield. - International Journal of Multidisciplinary Research and Development Online 2(12): 336-339.

[35] Lewis, D. C., McFarlane, J. D. (1986): Effect of foliar applied manganese on the growth of safflower (Carthamus tinctorius L.) and the diagnosis of manganese deficiency by plant tissue and seed analysis. - Australian Journal of Agricultural Research 37(6): 567572. 
[36] McCauley, A., Jones, C., Jacobsen, J. (2009): Nutrient Management. - Nutrient Management Module 9. Montana State University Extension Service Publication 4449(9): 1-16.

[37] Mengel, K., Kirkby, E. A. (2001): Principles of Plant Nutrition. 5th Ed. - Kluwer Academic Publishers, Dordrecht.

[38] Nagaraj, G., Devi, G. N., Surivas, C. V. S. (2001): Safflower petals and their chemical composition. - Proc. V. International Safflower Conference, July 23-27, USA.

[39] Nimbkar, N. (2002): Safflower rediscovered. - Times Agricultural Journal 2(1): 32-36.

[40] Nosheen, A., Bano, A., Ullah, F., Farooq, U., Yasmin, H., Hussain, I. (2011): Effect of plant growth promoting rhizobacteria on root morphology of Safflower (Carthamus tinctorius L.). - African Journal of Biotechnology 10(59): 12639-12649.

[41] Ogut, H., Oguz, H. (2006): Biodiesel: Third Millennium Fuel. - Nobel Publication, Ankara, pp. 55-60.

[42] Pongracz, G., Weiser, H., Matzinger, D. (1995): Tocopherol, Antioxidation. - Journal of Natural Fatty Acid Science and Technology 97: 90-104.

[43] Rajvanshi, A. K. (2005): - In: Esendal, E. (ed.) VI ${ }^{\text {th }}$ International Safflower Conference, Istanbul, Turkey, 6-10 June 2005, pp. 80-85.

[44] Revanth Nathan, J. K., Madhavi Lata, A., Joseph, B., Madhavi, A. (2018): Influence of nitrogen and sulphur on growth yield and economics of spineless safflower under irrigated conditions. - Int. J. Pure App. Biosci. 6(3): 77-81.

[45] Singh, R. K., Singh, A. K. (2013): Effect of nitrogen, phosphorus and sulphur fertilization on productivity, nutrient-use efficiency and economics of safflower (Carthamus tinctorius L.) under late-sown condition. - Indian Journal of Agronomy 58(4): 583-586.

[46] Soleymani, A., Shahrajabian, M. H. (2011): Effect of planting dates and different levels of nitrogen on seed yield and yield components of safflower grown after harvesting of corn in Isfahan, Iran. - Research on Crops 12(3): 739-743.

[47] Strasil, Z., Vorlicek, Z. (2002): The effect of nitrogen fertilization, sowing rates and site on yields and yield components of selected varieties of safflower (Carthamus tinctorius L.). - Rostlinna Vyroba. 48(7): 307-311.

[48] Taha, M. H., Shalaby, E. A., Nermeen, T. S. (2013): Improving safflower (Carthamus tinctorius L.) growth and biological activities under saline water irrigation by using iron and zinc foliar applications. - J. Plant Production, Mansoura Univ. 4(8): 1219-1234.

[49] Weiss, E. A. (2000): Castor, Sesame, and Safflower. - Barnes and Noble, Inc., New York, pp. 529-44. 